\title{
Prehistory of the British Isles: A Tale of Coming and Going*
}

\section{La préhistoire des îles britanniques : une histoire de va-et-vient}

\author{
I. De Groote - M. Lewis - C. Stringer
}

Received: 8 May 2017; Accepted: 11 July 2017

C Société d'Anthropologie de Paris et Lavoisier SAS 2017

\begin{abstract}
It is now recognised that Britain has not always been geographically isolated from Europe and, for most of the last one million years, formed an extension of the northwest European landmass. During most of this time, Britain was accessible to migrating humans and animals, although climatic conditions varied greatly from Mediterranean-like through to glaciations and extreme cold, making Britain a difficult place to settle for any length of time. The oldest evidence for humans in Britain dates to between about 850,000 and 1 million years ago. Recovered lithic artefacts suggest that hominin species occupied and deserted the British Isles at least nine times. This article reviews the prehistory of the British Isles and presents the main sites and time periods.
\end{abstract}

Keywords Pleistocene $\cdot$ Palaeolithic $\cdot$ Migration ·

Homo sapiens · Homo neanderthalensis ·

Homo heidelbergensis $\cdot$ Homo antecessor

Résumé Il est bien connu que les îles britanniques n'ont pas toujours été des îles et que pendant la plus grande partie du dernier million d'années, elles faisaient partie d'une péninsule s'étendant à partir (ou à l'extrémité) du Nord-Ouest de l'Europe. Cette région était alors accessible aux Hommes et aux animaux venant du continent. Les conditions climatiques ont varié entre celles trouvées aujourd'hui en Médi-

\footnotetext{
I. De Groote $(\bowtie)$

Research Centre in Evolutionary Anthropology and

Palaeoecology, School of Natural Sciences and Psychology,

John Moores University, Liverpool, UK

e-mail : I.E.DeGroote@ljmu.ac.uk

M. Lewis · C. Stringer

Earth Sciences Department, Natural History Museum, London, UK

* This is an invited contribution following the Annual Meeting of the SAP
}

terranée et les conditions désertiques des régions polaires, rendant la Grande-Bretagne un endroit difficile à habiter. La plus ancienne preuve de présence humaine en GrandeBretagne date entre 850000 et 1 million d'années. Les industries lithiques suggèrent que les espèces d'homininés se sont depuis installées puis ont déserté les îles britanniques au moins neuf fois. Dans cet article, nous proposons une revue des connaissances sur la préhistoire des îles britanniques, à partir des principaux sites et périodes correspondantes.

Mots clés Pléistocène $\cdot$ Paléolithique · Migration ·

Homo sapiens · Homo neanderthalensis .

Homo heidelbergensis $\cdot$ Homo antecessor

\section{Introduction}

When did the first humans arrive in what is now known as the British Isles? It is well known that the British Isles were not always islands and for most of the last one million years, they formed part of a peninsula extending from northwest Europe, potentially accessible by migrating humans and animals. Britain was not a straightforward place to settle, however, with the local climate oscillating between temperatures similar to those found in the modern Mediterranean through to polar desert conditions. Humans were able to migrate temporarily into the territory but were repeatedly pushed out by successive ice ages. The process of colonisation was repeated at least nine times, but when the last British ice sheets began to melt around 12,000 years ago, a new wave of migrants was able to settle more permanently. The main Palaeolithic sites in Britain presented in this review are shown in Table 1. Lithic artefacts of varying industries and ages have been found across most of Britain from its one-million-year-long human history, but human fossil remains are few. This article provides an overview of the presence of humans in the British Isles and their tale of coming and going. 


\begin{tabular}{|c|c|c|c|}
\hline Site & Industry & Age & Dating method \\
\hline Happisburgh 3 & Lower Palaeolithic & $\begin{array}{l}950,000-850,000 \text { BP Early } \\
\text { Pleistocene; MIS } 25 \text { or } 21\end{array}$ & Palaeomagnetism, biostratigraphy \\
\hline Pakefield & Lower Palaeolithic & $\begin{array}{l}750,000-680,000 \mathrm{BP} ; \mathrm{MIS} \\
19 \text { or } 17\end{array}$ & $\begin{array}{l}\text { Lithostratigraphy, biostratigraphy, AAR, } \\
\text { palaeomagnetism }\end{array}$ \\
\hline West Runton & None & 700,000 BP; MIS 17 & AAR, biostratigraphy \\
\hline Boxgrove & Lower Palaeolithic & 500,000 BP; MIS 13 & Lithostratigraphy, biostratigraphy \\
\hline Swanscombe & Lower Palaeolithic & 400,000 BP; MIS 11 & Lithostratigraphy, biostratigraphy AAR \\
\hline Baker's Hole & Levallois & MIS $8 / 7$ & AAR, biostratigraphy \\
\hline Pontnewydd Cave & Levallois & $\sim 225,000$ BP; MIS 7a & U-series, ESR, TL, biostratigraphy \\
\hline Crayford & Levallois & MIS 7a & AAR, biostratigraphy \\
\hline La Cotte & Levallois & MIS 7 to 2 & OSL, 14C, TL, biostratigraphy \\
\hline Lynford Quarry & Middle Palaeolithic & $\sim 60,000$ BP; MIS 4/3 & OSL $(+14 C)$ \\
\hline Kent's Cavern & Middle \& Upper Palaeolithic & Maxilla $\sim 40,000$ BP; MIS 3 & $14 \mathrm{C}$, biostratigraphy \\
\hline Paviland & Upper Palaeolithic & Burial $~ 34,000 \mathrm{BP}$; MIS 3 & $14 \mathrm{C}$ \\
\hline Church Hole & Middle \& Upper Palaeolithic & MIS 3 to 1 & U-series, $14 \mathrm{C}$ \\
\hline Gough's Cave & Late Upper Palaeolithic & 14,700 BP; MIS 2 & $14 \mathrm{C}$ \\
\hline \multicolumn{4}{|c|}{$\begin{array}{l}\text { BP: before present; AAR: amino acid racemisation; OSL: optically stimulated luminescence; TL: thermoluminescence; U-series: Ura- } \\
\text { nium series; 14C: Ultra filtered radiocarbon; MIS: Marine Isotope Stage / BP : avant le présent ; AAR : racémisation des acides } \\
\text { aminés ; OSL : luminescence stipulée optiquement ; U-series : séries de l'uranium ; 14C : radiocarbone avec ultrafiltration ; MIS : } \\
\text { stades isotopiques marins } \\
\text { References: HSB } 3 \text { [4]; Pakefield [7,51]; West Runton [10,51]; Boxgrove [11]; Swanscombe [23,51]; Baker's Hole [24,51]; Pontne- } \\
\text { wydd [52]; La Cotte [31,32]; Lynford [36,37]; Kent's Cavern [39]; Paviland [40]; Church Hole [46,53]; Gough's Cave [43] }\end{array}$} \\
\hline
\end{tabular}

\section{The first explorers (1 million $-475,000$ years ago)}

\section{Connected lands}

From the early Pleistocene, Britain was connected to mainland Europe by a land-bridge that enabled humans and fauna to migrate in and out (Fig. 1A). Until about 130,000 years ago, this narrow chalk isthmus, separating the north (North Sea) and southwest (English Channel) marine embayments, kept Britain connected to varying extents even when sealevels were high during the warm interglacial periods [2]; the eventual complete breaching of this chalk barrier was crucial in forming the island and the Dover Strait. During glacial periods, much of the earth's water would have been trapped in the ice caps and when, during the later Pleistocene, the bed of the North Sea was exposed, a large land area known as Doggerland, created by geological uplift and sedimentation from rivers, also provided a route into the British Isles and fauna, including hominins, would have entered this way. The flooding of the shallow shelf areas of the English Channel and the North Sea are the consequence of the current high interglacial sea levels.

\section{The main sites and their evidence}

The site with the oldest evidence for humans in the British Isles is at Happisburgh, Norfolk, now located on the eastern English coast (Figs. 2, 3) [3,4]. During the late Early Pleistocene (between about 1 and 0.78 million years ago), Happisburgh formed part of a large river estuary, close to the confluence of the now extinct Bytham and the palaeoThames (currently flowing further south through London) [5]. The Happisburgh sites, now numbering more than five localities, are situated on and near the present-day beach. The cliffs are composed of till deposited by glaciers with laminae of undisturbed bedding surfaces beneath. The sediments at the base of the cliffs (Happisburgh site 3) were excavated between 2005 and 2010, and around 80 lithic artefacts were discovered dating broadly to between 850,000 and 950,000 years ago, the oldest known stone tools in northwest Europe [4]. A borehole through the cliffs to the underlying estuarine sediments was taken in May 2013. 

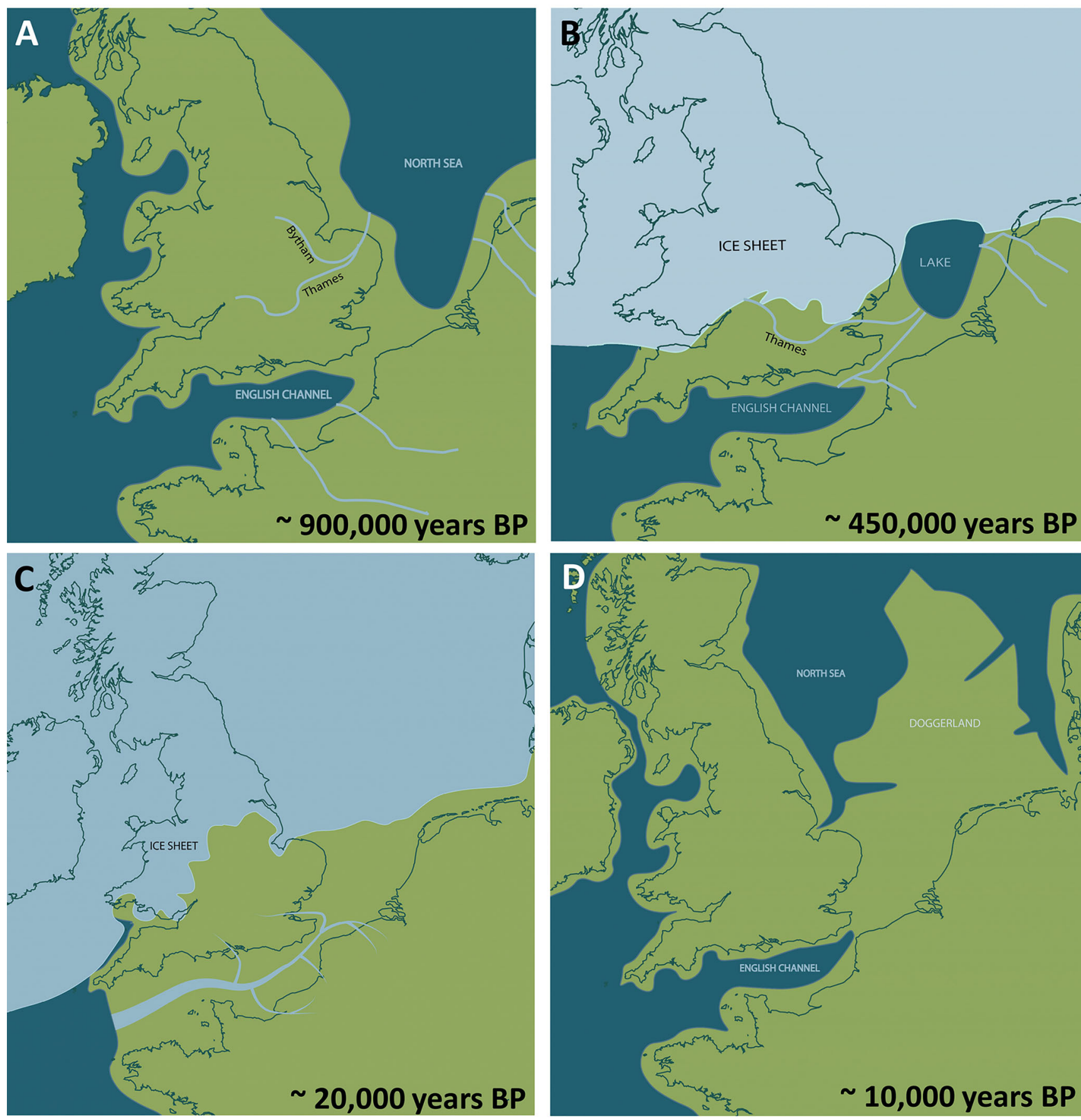

Fig. 1 Generalised reconstruction of the land surface and the extent of ice sheets of the British Isles. A. $\sim 900,000$ years BP. B. 450,000 BP (MIS 12 - Elsterian Glaciation). C. 20,000 years BP (MIS 2 - Last Glacial Maximum). D. 10,000 years BP (MIS 1 Early Holocene) (after Stringer [1]) / Reconstitution des surfaces émergées et de l'étendue des glaciers sur les îles Britanniques. A. 900000 ans BP. B. 450 000 BP (SIM 12 - Glaciation Elsterienne). C. 20000 ans BP (SIM 2 - Dernier Maximum Glaciaire). D. 10000 ans BP (SIM 1 - Holocène ancien) (d'après Stringer [1])

Results show that these sediments are predominantly estuarine sands and silts forming the infill of channels with intermittent gravel deposits. The gravel deposits, up to $20 \mathrm{~cm}$ in thickness, within these sands and silts have yielded flint flakes and cores. In addition, a rich assemblage of flora and fauna has allowed their attribution to the latter part of an interglacial during the late Early Pleistocene, perhaps Marine Isotope Stage (MIS) 21 or 25.

In May 2013, a footprint surface was discovered near Happisburgh site 3 and was found to be in the same complex 


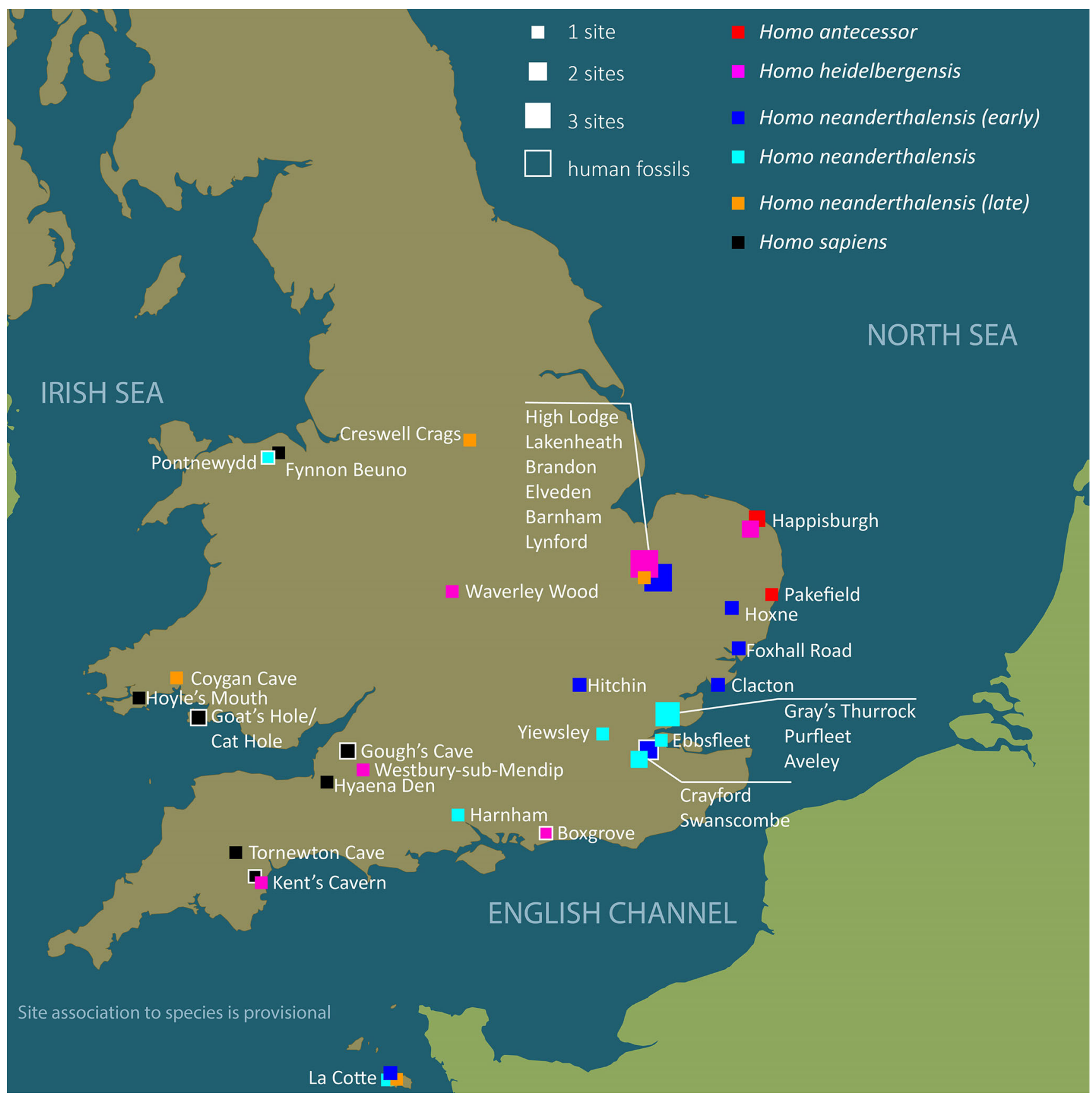

Fig. 2 Current distribution of the main Palaeolithic archaeological sites of the British Isles / Distribution actuelle des principaux sites archéologiques du Paléolithique des îles Britanniques

of channel fills as the archaeological layers [3]. The exposure of the laminated silts through coastal erosion is frequent at Happisburgh and usually takes the form of flat or gently undulating surfaces. The exposed surface, approximately $12 \mathrm{~m}^{2}$, showed very different characteristics with a series of hollows from circular to elongate, and the visual similarity to other coastal footprint surfaces in Britain (e.g. Formby, Sefton Coast [6]) prompted analyses of these hollows. The surface was located in the intertidal zone and subsequently eroded by tidal action over a period of two weeks, until the footprints were completely destroyed. The footprints may well have been left by Homo antecessor, the only hominin species so far known in Europe at that time [3].

Although no human fossils have been found at Pakefield (Suffolk), flint artefacts dating back approximately 700,000 years were, until the more recent Happisburgh discoveries, the earliest evidence for human presence in Britain (Fig. 4) [7]. The presence of hippopotamus, elephant, lion 


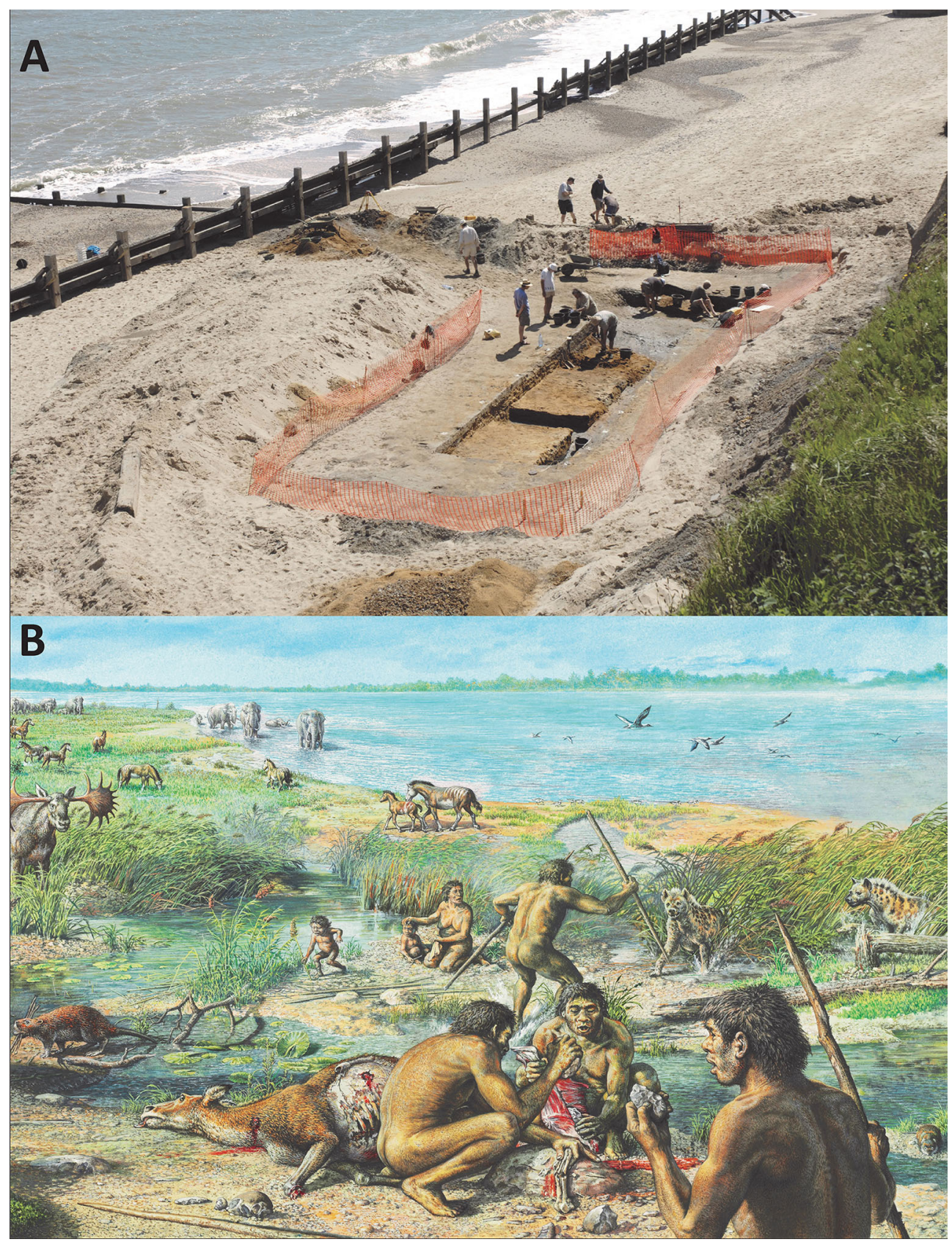

Fig. 3 Happisburgh, Norfolk. A. Site 3 excavation (courtesy of NHM, London). B. Artist's reconstruction of the environment at Happisburgh $\sim 900,000$ years BP (courtesy of John Sibbick and the AHOB Project) / Happisburgh, Norfolk. A. Fouilles du site 3 (NHM, London). B. Vue d'artiste de l'environnement à Happisburgh il y a 900 000 ans BP (John Sibbick et le projet AHOB)

and deer remains, as well as analyses of sediments and pollen, suggest the climate of the British Isles was warmer than at the earlier Happisburgh 3 site, with summers as warm as those in the Mediterranean today [7-9]. At West Runton, on the North Norfolk coast, an almost complete skeleton of a mammoth was found in 1990, the largest and oldest steppe mammoth skeleton found in Britain, dating to about 700,000 years ago, but no evidence of human occupation was found at the site [10]. Climatic conditions at West Run- ton were similar to those today. However, from soon after this time climatic oscillations became more extreme and Britain was regularly plunged into severe 'Ice Ages', experiencing the effects of ice sheets reaching the lower latitudes and the chilling of the North Atlantic.

Archaeological excavations at Boxgrove, in Sussex, England, uncovered a land surface with freshwater pools where animals gathered, dating from about 500,000 years ago (Fig. 5). As well as the butchered bones of a range of 


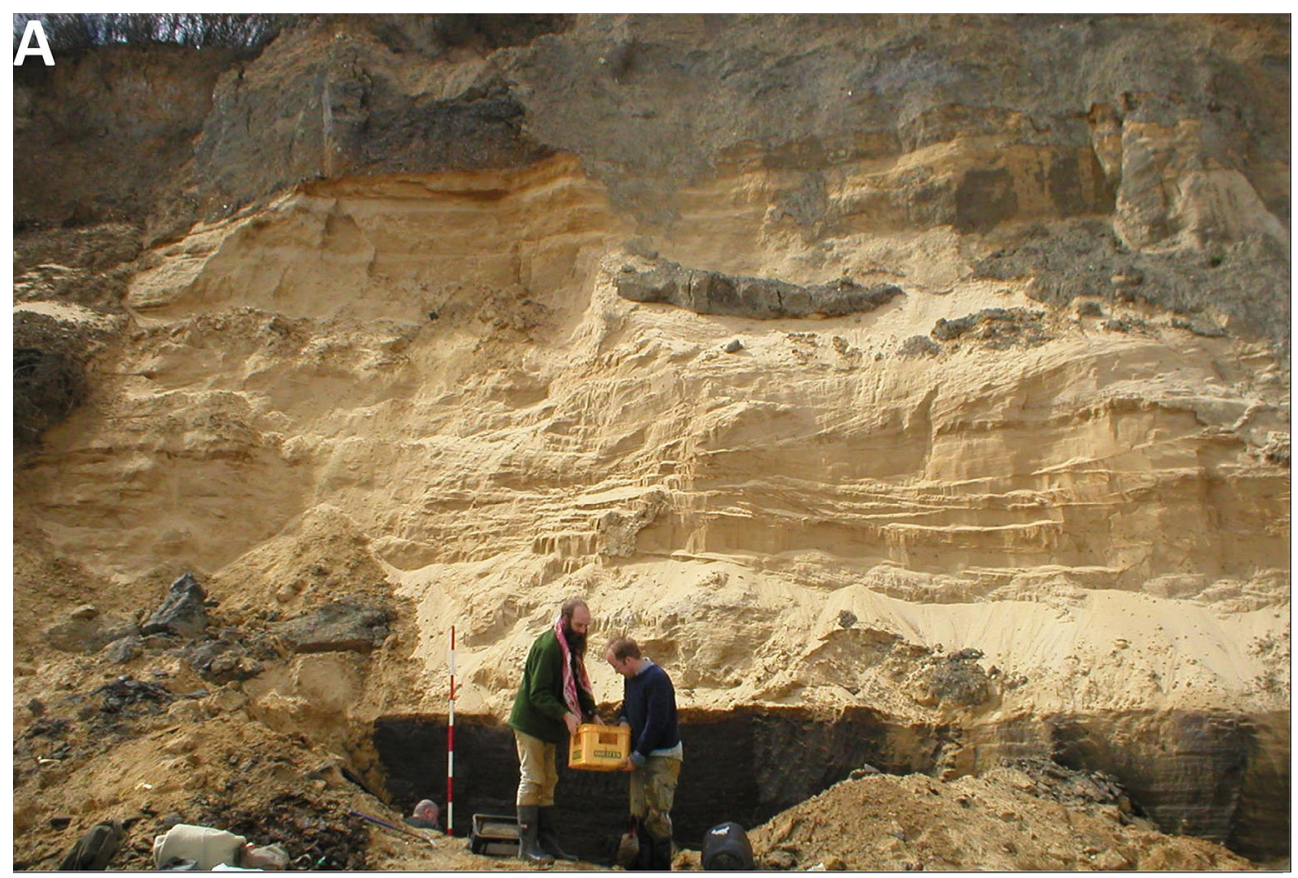

B

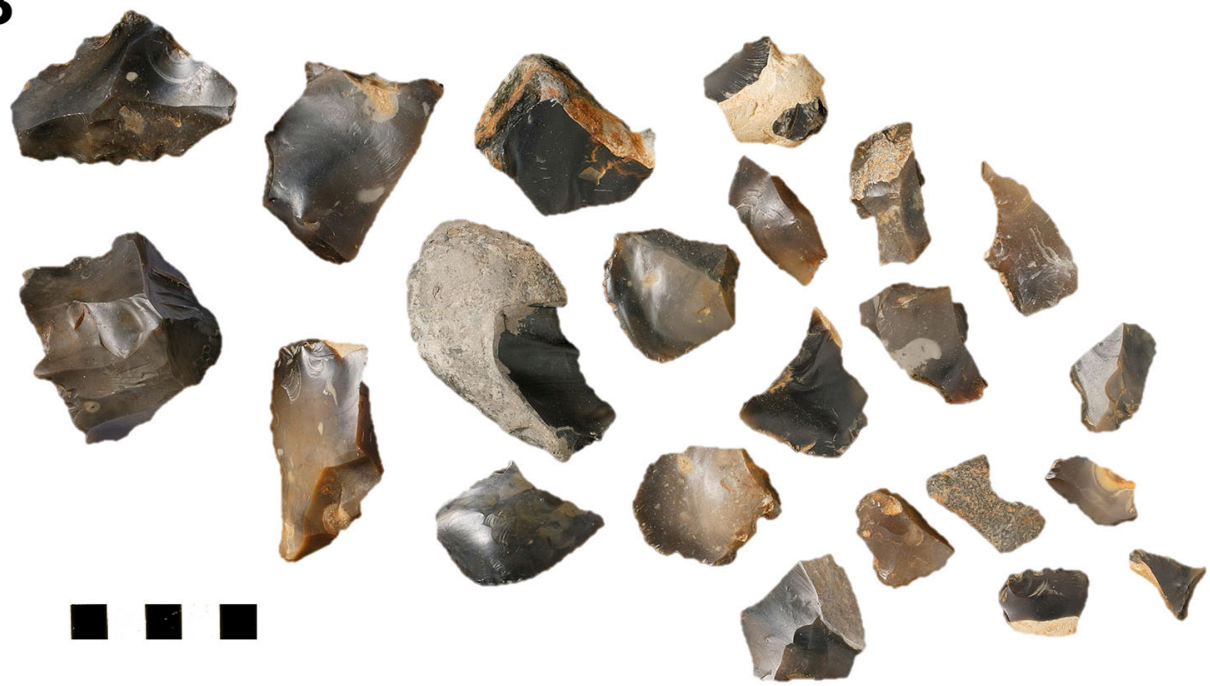

Fig. 4 Pakefield, Norfolk. A. Excavation at Pakefield with the Cromer Forest-bed deposits clearly visible at base of cliff. B. Flint artefacts recovered from the site (courtesy of NHM, London) / Pakefield, Norfolk. A. Fouilles à Pakefield avec le niveau sédimentaire de forêt du Cromérien clairement visible à la base du remplissage. B. Artefacts en silex découverts dans le site (NHM, London)

herbivores such as rhinoceros, horse and deer, large numbers of Acheulian handaxes were discovered [11,12]. These tools are more sophisticated than those found at Happisburgh and Pakefield, and the earliest British human fossils, a tibia and two teeth, were uncovered here in association with the cutmarked animal bones and handaxes [13]. Around 475,000 years ago we see the onset of the most severe cold stage of the Middle and Late Pleistocene, known as the Anglian (or Elsterian), with ice sheets extending far into southern Britain, making it uninhabitable.

\section{Hominins}

There are no Homo antecessor fossils currently known from Britain, but the footprint surface associated with Happisburgh 3 , with a range of juvenile to adult hominin foot sizes, may be evidence of that species. Using foot length to stature ratios, the hominins who left the prints were estimated to have been between $0.93 \mathrm{~m}$ and $1.73 \mathrm{~m}$ in height, which suggests that the group consisted of individuals of different ages [3]. The estimated adult statures of the 

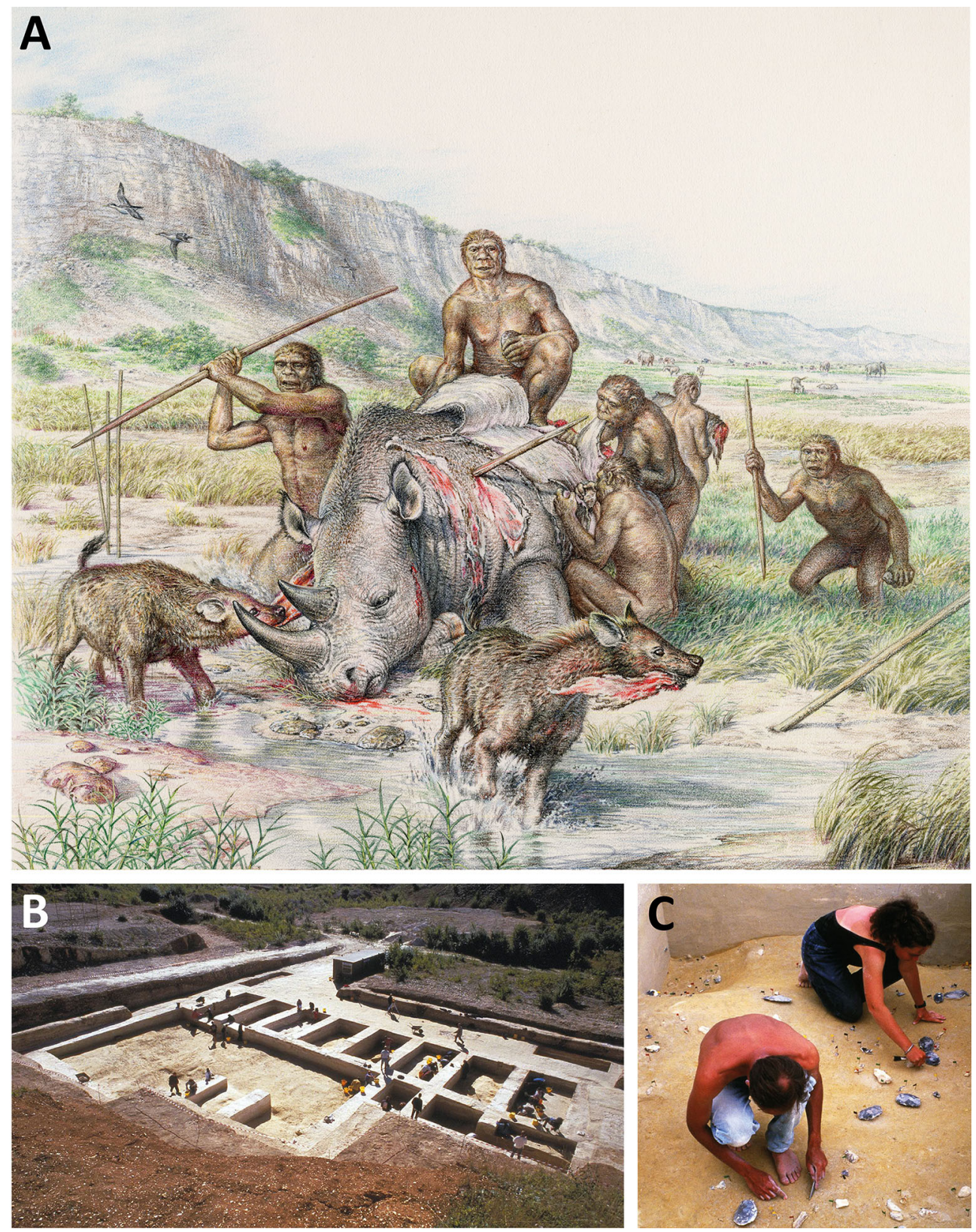

Fig. 5 Boxgrove, West Sussex. A. Reconstruction of butchering of a rhinoceros at the Boxgrove site (courtesy of John Sibbick). B. Excavations at Boxgrove. C. A rich assemblage of handaxes being excavated / Boxgrove, West Sussex. A. Reconstruction du découpage d'un rhinocéros sur le site de Boxgrove (John Sibbick). B. Fouilles à Boxgrove. C. Un riche assemblage de bifaces a été découvert

hominins from Happisburgh fall within the range derived from the fossil evidence of Homo antecessor, the only known species in western Europe of a similar age and known only from fossils found at the site of Gran Dolina, Atapuerca, Spain and dated to about 860,000-780,000 years ago. The species is believed to have evolved from Homo erectus, but had unique features that distinguish it from other Homo species [14-17]. A number of lithic artefacts similar in typology to those found at Gran Dolina were found at Happisburgh.
Animal remains at these early Pleistocene sites suggest that the climate was largely warm but this changed after about 650,000 years ago. At times, conditions throughout Europe became harsh and cold and Britain became uninhabitable. It is unclear whether Homo antecessor gave rise to Homo heidelbergensis, and subsequently to Neanderthals, or whether they were an evolutionary dead-end.

Homo heidelbergensis is the earliest human species for which we have fossil evidence in Britain, from around 500,000 years ago at Boxgrove. Two lower incisors were 
found close to one another and probably belong to the same adult individual. The morphology of the teeth is similar to that of other middle Pleistocene hominins making their assignment to Homo heidelbergensis possible. The tibia most likely originated from a different individual because it was discovered in a different stratigraphic context from the two teeth [18]. The tibia reveals a mosaic morphology relative to other archaic Homo tibiae. The external diaphyseal robusticity and mediolaterally thickened cortical bone distribution are characteristic of Late Pliocene to Late Pleistocene archaic Homo. The estimated cold-adapted body proportions would have promoted body heat conservation in a hominin practicing minimal cultural buffering during the late interglacial cool temperate climate [19]. From the Boxgrove tibia, it has been shown that Homo heidelbergensis was taller than the later, cold-adapted, Neanderthals [20]. Although no other British sites have yielded Homo heidelbergensis fossils, some have yielded similar lithic artefacts to those found at Boxgrove, Brandon and Waverley Wood, for example [11,21]. The tools associated with Homo heidelbergensis were more varied than those of Homo antecessor and included bifacial handaxes, cleavers and scrapers; they were probably skilled hunters of large animals, such as rhinoceros, bear, horse and deer [11].

\section{The colonisers $(425,000-40,000$ years ago $)$}

\section{Connected or disconnected?}

Britain's history of connectivity to mainland Europe is complex. However, in broad terms around 450,000 years ago (MIS 12), ice stretched across the North Sea, from Britain to Scandinavia, and at the end of this glacial stage there was an initial breaching of the chalk ridge (Fig. 1B). This initial erosion of the land bridge was probably characterised by waterfalls and channels that would have emptied proglacial lakes in the southern North Sea basin [2]. During the following glacial periods, Britain would have been too cold to inhabit and Neanderthals would have been pushed out of the British Isles to return during the interglacials. From around 180,000 years ago, there was a steady decline in global temperature which must have forced the Neanderthals out of Britain, and at about 160,000 years ago (MIS 6) it is unlikely that any humans were still present; however, the climate then recovered rapidly at around 130,000 years ago. This led to the rise of sea levels and the submerging of the land surface between Britain and the continent, making Britain an island. Some mammals, depending on the distances of their glacial refugia, were fast to migrate and managed to reach Britain before it became an island. Others, such as elephants and hippopotamus, may have swum across, but Neanderthals (without boats) are not thought to have returned until around 60,000 years ago [22].

\section{Coming and going: Ice ages and deserted lands}

Just over 400,000 years ago a rapid improvement of the climate after the Anglian glaciation made Britain habitable again. Swanscombe is the only British site, to date, where a very early Neanderthal fossil [23] has been discovered and it is possible that Neanderthals evolved from Homo heidelbergensis around this time (Fig. 6). The climate worsened again by about 375,000 years ago, driving these early Neanderthals out again. Neanderthals returned to Britain after the ice had retreated around 330,000 years ago, bringing with them new technologies. The Neanderthals are mostly known from sites across Britain with Mousterian artefacts, an industry which incorporates Levallois technique ${ }^{1}$. Baker's Hole (Ebbsfleet, Kent) is one of the foremost sites that shows the Levallois industry [24].

The oldest human fossils in Wales found until now came from Pontnewydd Cave, which has been dated to about 225,000 years ago [25,26], and comprise teeth of early Neanderthal adults and children (Fig. 7). The Mousterian industry was also found at Crayford, Kent [27,28]. Additionally, more than 250,000 lithic artefacts were found on the other side of the channel at the site of La Cotte and although this site is now on the island of Jersey, the island was connected to mainland France during periods of Neanderthal occupation. Generations of Neanderthals most likely returned to the site over a period totalling more than 150,000 years [29-32]. Although for a long time it was believed Neanderthals did not return to Britain until about 60,000 years ago, a recent discovery from Dartford (Kent), dated at about 100,000 years ago, may hint that small Neanderthal groups possibly made rare visits into Britain from their more permanent camps in France or Belgium [33,34]. It is possible that they followed herds of mammoths, rhinoceros, horse and deer into Britain, but further analyses and evidence are needed to support this claim.

Neanderthals were back in full force around 60,000 years ago. The site of Lynford Quarry, Norfolk has extensive evidence for classic Neanderthal Mousterian tools associated with the remains of at least eleven woolly mammoths [3537]. Although no butchery marks were found on the recovered mammal bones, none of the large meat-bearing bones were found, indicating they may have been transported away from the kill site.

\footnotetext{
${ }^{1}$ A method of stone reduction, involving the striking of flakes from a prepared core that provided much greater control over the size and shape of the final flakes which would then be employed as scrapers, knives and points.
} 


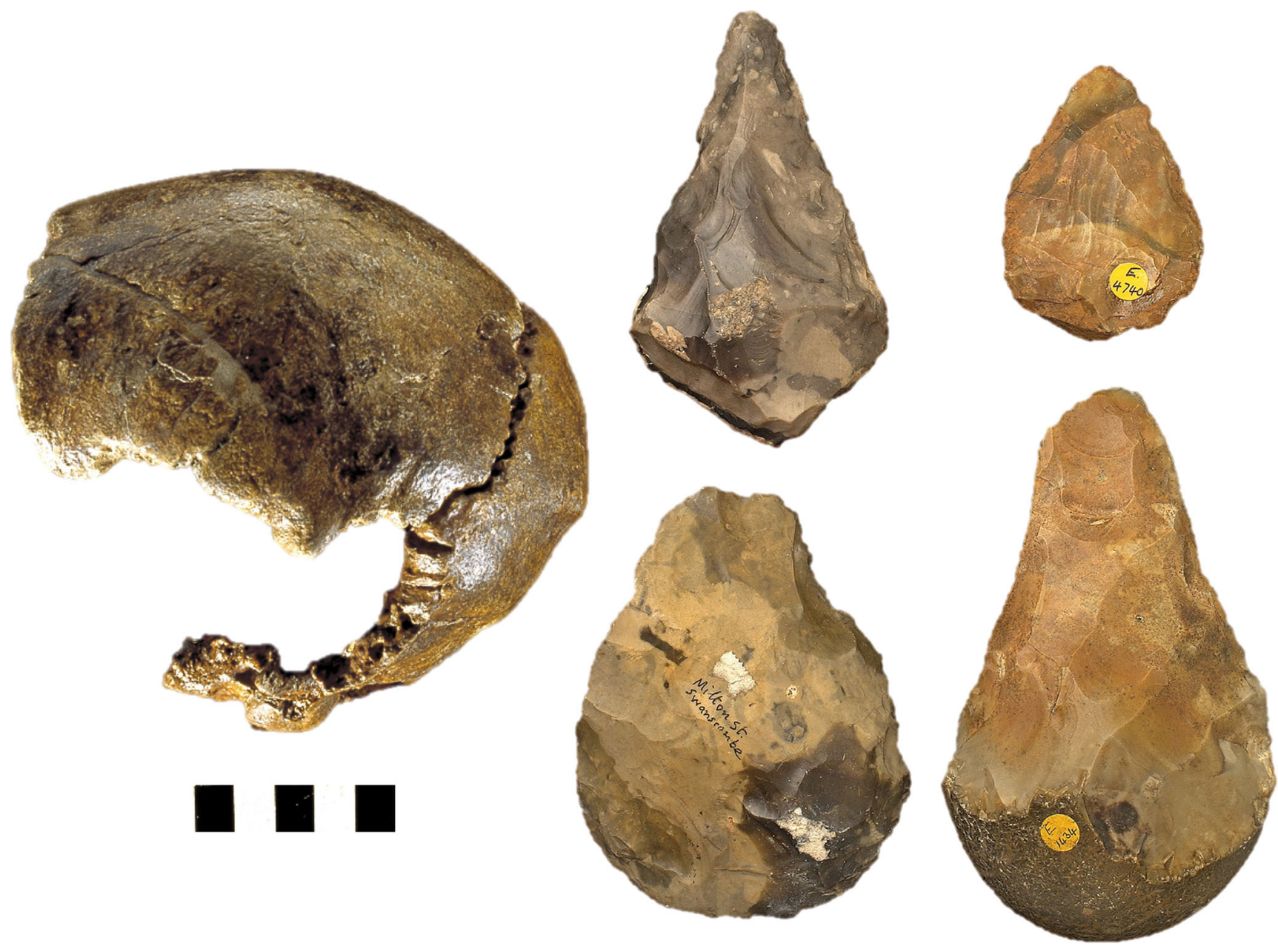

Fig. 6 Swanscombe, Kent. The partial cranium belonging to an early Neanderthal, probably female, and a selection of handaxes recovered at Swanscombe (courtesy of NHM, London) / Swanscombe, Kent. Le crâne partiel appartenant à un Néanderthalien ancien, probablement de sexe féminin et une sélection de bifaces découverts à Swanscombe (of NHM, London)

\section{Hominins}

The oldest fossil evidence for Neanderthals in the British Isles is the partial skull from Swanscombe. The three cranial bones were discovered between 1935 and 1955; the articulated bones form the back of the skull of what is believed to be an early Neanderthal female and were found close to a number of flint handaxes [23]. Despite its chronological association with the Middle Pleistocene, the occipital bone carries Neanderthal features: a weak occipital torus with bilateral projection, a central suprainiac depression and a strongly convex occipital plane. This makes the Swanscombe hominin one of the earliest primitive Neanderthals and supports an ancient root for the Neanderthal clade. The early emergence of these Neanderthal features in Swanscombe, while other roughly contemporary fossil hominins from Italy, Hungary and Germany display less derived Neanderthal morphology, suggests a more complex pattern of human evolution than has generally been assumed [20,23]. Neanderthal fossils were also found in Pontnewydd Cave, North Wales. The nineteen hominin teeth were associated with bifacial and Levallois artefacts and belonged to both juveniles and adults. The teeth are taurodont and the overall dental morphology shows clear affinities with Neanderthals and the pre-Neanderthal Middle Pleistocene teeth from the Sima de los Huesos, Atapuerca, Spain.

\section{The founding people $(40,000-10,000$ years ago)}

\section{An island established}

Neanderthals had returned to the British Isles by about 60,000 years ago, and although MIS 3 climate was variable and complex, conditions did not improve permanently until 


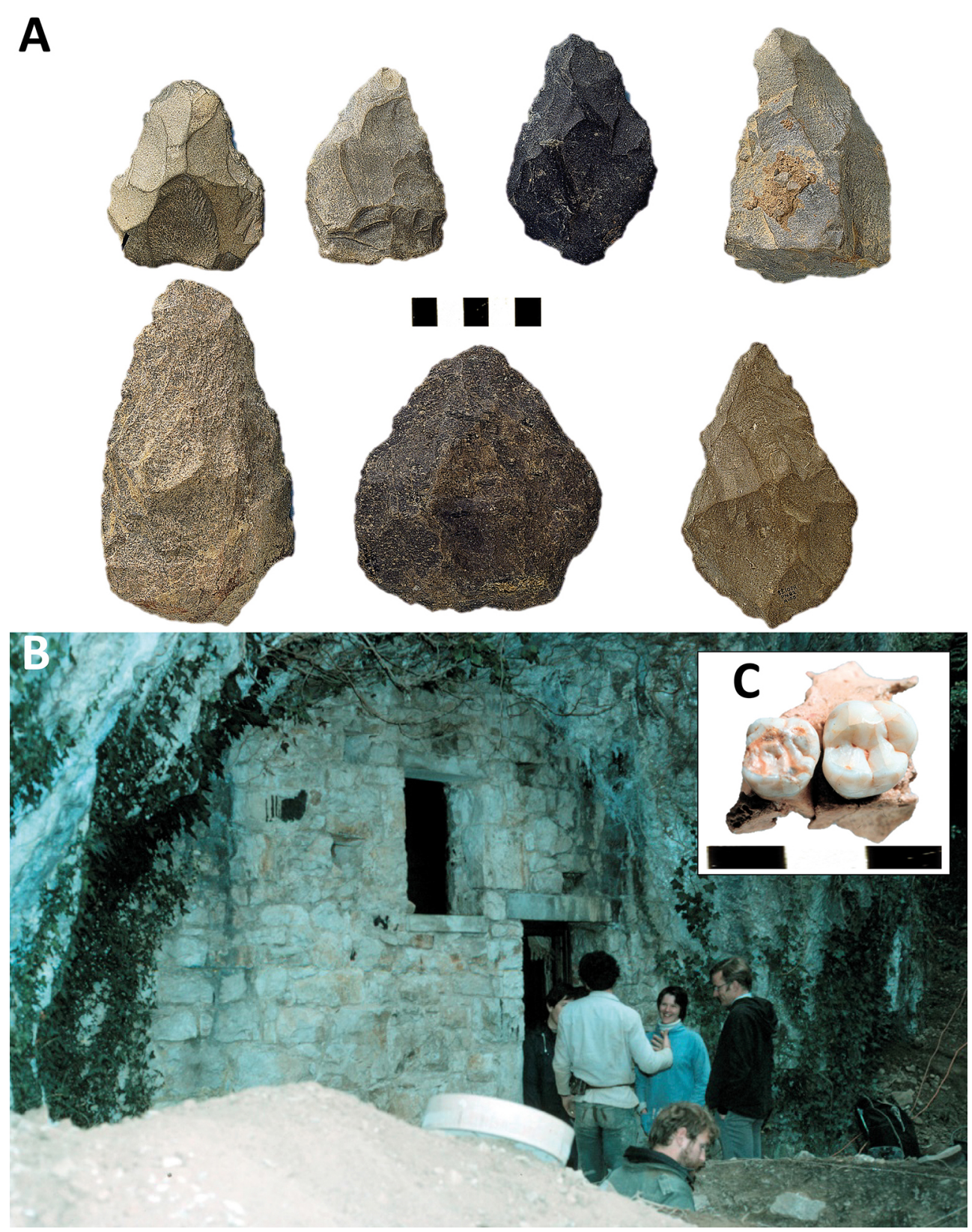

Fig. 7 Pontnewydd Cave, North Wales. A. Handaxes discovered at Pontnewydd Cave (courtesy of the National Museum of Wales). B. The cave entrance during excavations. C. A juvenile Neanderthal maxilla is part of the assemblage of 19 teeth discovered at the site (courtesy of the NHM, London) / Pontnewydd Cave, North Wales. A. Bifaces découverts dans la grotte de Pontnewydd (National Museum of Wales). B. L'entrée de la grotte durant les fouilles. C. Un maxillaire de Néanderthalien immature fait partie des 19 dents découvertes dans le site (NHM, London)

the end of the glacial period (MIS 2), which reached its cold peak around 20,000 years ago, the Last Glacial Maximum (Fig. 1C). During the early part of the current interglacial, the Holocene, Doggerland, the exposed land area in the present-day North Sea region, gradually disappeared as the ice melted and sea levels slowly rose to those of today (Fig. 1D). Well before this time (around 40,000 years ago), we see the demise of the Neanderthals and the arrival of Homo sapi- ens in Europe [38]. The role of modern humans in the physical extinction of the Neanderthals is the subject of much debate [38], but genetic data show that Neanderthal DNA entered the modern human gene pool through interbreeding events. At present, no evidence of overlap exists for the occupation of Britain by Neanderthals and modern humans; any interbreeding probably happened more centrally within the Neanderthal range rather than at its geographical limits. 


\section{Still coming and going}

The oldest modern human fossil in Britain, a fragment of maxilla, was found at Kent's Cavern (Fig. 8) and dates back to at least 40,000 years ago [39]. The "Red Lady of Paviland" (actually the skeleton of a young man initially wrongly identified as a female) was discovered at Goat's Hole, South Wales, in 1823. The skeleton was coated in red ochre and the body had been buried wearing jewellery made from mammoth tusks; recent dating to about 33,000 years makes this discovery the oldest ceremonial burial in western Europe [40]. During the Last Glacial Maximum much of northern Britain and upland Wales would have been under an ice sheet that was up to $1 \mathrm{~km}$ thick in places, and cold winds and dry air would have prevailed across Britain. This severe environment seems to have been too difficult to deal with, even for the resourceful first modern humans, and Britain was deserted once more, probably by around 28,000 years ago [41].

Around 15,000 years ago the climate started to improve and the ice gradually retreated making Britain, once again, a welcome place for large game and the hunters who followed them [42]. Gough's Cave in Cheddar Gorge was one of the first settlements for Magdalenian modern humans after the peak of the last glacial stage [43]. Not only did these humans bring with them finely decorated bone tools, like batons and needles, they also made cups out of human skulls $[44,45]$. For a long time, it was believed that one of the main differences between early British and mainland European modern human sites was the absence of figurative art, such as figurines and cave paintings or engravings. In 2004 however, an engraving at least 13,000 years old of a bison, similar in style to those found in European caves, was found at Church Hole

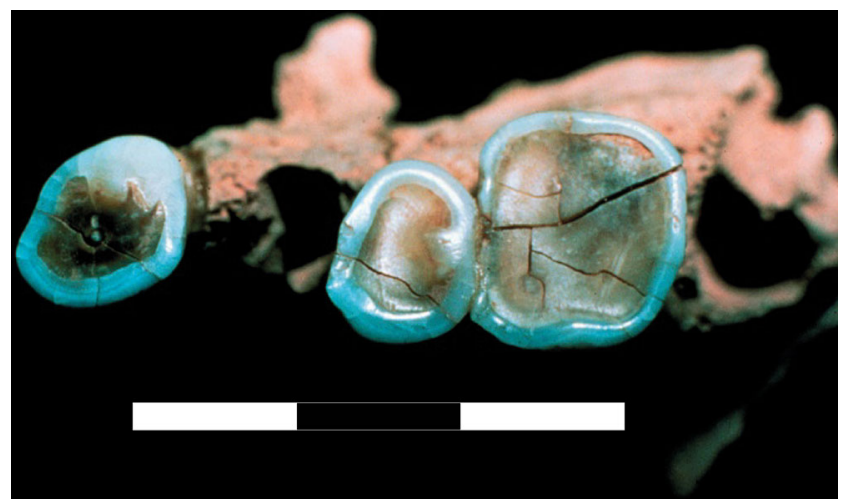

Fig. 8 The maxilla from Kent's Cavern, Devon, including three teeth of the earliest known modern human in Britain, discovered during excavations in 1927 / Le Maxillaire de la grotte de Kent, Devon, qui comprend trois dents et correspond au plus ancien Homme moderne connu en Grande-Bretagne, trouvé lors de fouilles en 1927 in the English midlands [46]. Shortly after 13,000 years ago another brief cold period hit Europe, but by about 11,700 years ago the current interglacial had started and temperatures gradually reached what they are today $[47,48]$. Prehistoric hunter-gatherers coming from Europe had to deal with new challenges. The animals they were used to hunting on the European Steppe, such as reindeer and horse, were replaced by forest dwelling taxa such as deer and wild boar. Around 6000 years ago, new ideas of agriculture and animal husbandry arrived from Europe leading to the decline of the hunter-gathering way of life and the beginning of the Neolithic $[49,50]$. As well as the adoption of agriculture, technological advances and a more sedentary way of life, these farming communities also implemented the construction of the first monuments in the landscape, such as Stonehenge 4600 years ago [49].

\section{Conclusion}

This review has laid out how human occupation of the British Isles during the last one million years is a story of repeated migration. The changing environment, with temperatures decreasing and recovering during the glacials and interglacials, would have posed challenges to the humans and fauna that they would not have encountered in more southerly parts of Europe. Not only would the English Channel land area have been submerged or dissected by large rivers at times, making accessing Britain difficult or impossible, but also when the ice sheets were at their thickest the extreme cold would have made the area uninhabitable for long periods of time. The first hominins to venture into the British Isles, probably Homo antecessor and Homo heidelbergensis, would have been unable to survive these long cold periods. Even Neanderthals, a human species well adapted to living in the cold northwest European plains, seem to have been unable to survive in Britain during MIS 6. Modern humans, despite their controlled use of fire, building of shelters and advanced lithic technology, still needed several attempts before being able to settle because life at the western edge of the Old World was not easy. The prehistory of the British Isles is a tale of coming and going of deserted, lands and recurring migrations.

Acknowledgements We would like to thank Simon Parfitt and also the Photography Unit at the Natural History Museum, London, for some of the images used; John Sibbick for the Happisburgh and Boxgrove reconstructions; Elizabeth Walker and Kay Kays from the National Museum of Wales for the Pontnewydd lithics image. CBS and ML's research work was supported through the AHOB Project, funded by the Leverhulme Trust, and Pathways to Ancient Britain, funded by the Calleva Foundation. 


\section{Conflict of interest: None.}

\section{References}

1. Stringer C (2006) Homo britannicus. London, Allen Lane, London. 319 pp.

2. Gupta S, Collier JS, Garcia Moreno D, et al (2017) Two-stage opening of the Dover Strait and the origin of island Britain. Nat Commun 8:e15101

3. Ashton N, Lewis SG, De Groote I, et al (2014) Hominin footprints from early pleistocene deposits at happisburgh, UK. PLoS One 9:e88329

4. Parfitt SA, Ashton NM, Lewis SG, et al (2010) Early Pleistocene human occupation at the edge of the boreal zone in northwest Europe. Nature 466:229-33

5. Lee JR, Rose J, Hamblin RJ, et al (2004) Dating the earliest lowland glaciation of eastern England: a pre-MIS 12 early Middle Pleistocene Happisburgh glaciation. Quat Sci Rev 23:1551-66

6. Huddart D, Roberts G, Gonzalez S (1999) Holocene human and animal footprints and their relationships with coastal environmental change, Formby Point, NW England. Quat Int 55:29-41

7. Parfitt SA, Barendregt RW, Breda M, et al (2005) The earliest record of human activity in northern Europe. Nature 438:1008-12

8. Ashton N, Lewis SG (2012) The environmental contexts of early human occupation of northwest Europe: The British Lower Palaeolithic record. Quat Int 271:50-64

9. Stuart A, Lister AM (2001) The mammalian faunas of Pakefield/ Kessingland and Corton, Suffolk, UK: evidence for a new temperate episode in the British early Middle Pleistocene. Quat Sci Rev 20:1677-92

10. Lister AM, Stuart AJ (2010) The West Runton mammoth (Mammuthus trogontherii) and its evolutionary significance. Quat Int 228:180-209

11. Roberts MB, Parfitt SA (1999) Boxgrove: A Middle Pleistocene Hominid site at Eartham Quarry, Boxgrove, West Sussex, English Heritage. In: English Heritage. 484 pp

12. Stringer CB (1996) The Boxgrove tibia: Britain's oldest hominid and its place in the Middle Pleistocene record. In: Gamble $\mathrm{C}$ and Lawson AJ (eds): The English Palaeolithic Reviewed. Trust for Wessex Archaeology Ltd, pp. 52-6

13. Roberts MB, Stringer CB, Parfitt S (1994) A hominid tibia from Middle Pleistocene sediments at Boxgrove, UK. Nature 369:311

14. Fernandez-Jalvo Y, Carlos Diez J, Cacares I, et al (1999) Human cannibalism in the Early Pleistocene of Europe (Gran Dolina, Sierra de Atapuerca, Burgos, Spain). J Hum Evol 37:591-622

15. Lorenzo C, Arsuaga JL, Carretero JM (1999) Hand and foot remains from the Gran Dolina Early Pleistocene site (Sierra de Atapuerca, Spain). J Hum Evol 37:501-22

16. Carretero JM, Lorenzo C, Arsuaga JL (1999) Axial and appendicular skeleton of Homo antecessor. J Hum Evol 37:459-99

17. Arsuaga J-L, Martínez I, Lorenzo C, et al (1999) The human cranial remains from Gran Dolina lower Pleistocene site (Sierra de Atapuerca, Spain). J Hum Evol 37:431-57

18. Hillson S, Parfitt S, Bello S, et al (2010) Two hominin incisor teeth from the middle Pleistocene site of Boxgrove, Sussex, England. J Hum Evol 59:493-503

19. Trinkaus E, Stringer C, Ruff C, et al (1999) Diaphyseal crosssectional geometry of the Boxgrove 1 Middle Pleistocene human tibia. J Hum Evol 37:1-25

20. Buck LT, Stringer CB (2014) Homo heidelbergensis. Curr Biol 24:R214-R5

21. Stout D, Apel J, Commander J, et al (2014) Late Acheulean technology and cognition at Boxgrove, UK. J Archaeol Sci 41:576-90
22. Ashton N (2002) Absence of humans in Britain during the last interglacial (oxygen isotope stage 5e). Publications du CERP 8:93-103

23. Stringer C, Hublin JJ (1999) New age estimates for the Swanscombe hominid, and their significance for human evolution. J Hum Evol 37:873-7

24. Scott B, Ashton N, Penkman KE, et al (2010) The position and context of Middle Palaeolithic industries from the Ebbsfleet Valley, Kent, UK. J Quat Sci 25:931-44

25. Green H, Stringer C, Collcutt S, et al (1981) Pontnewydd Cave in Wales - a new Middle Pleistocene hominid site. Nature 294:707-13

26. Compton T, Stringer C (2015) The morphological affinities of the Middle Pleistocene hominin teeth from Pontnewydd Cave, Wales. J Quat Sci 30:713-30

27. Roe DA (2014) The Lower and Middle Palaeolithic periods in Britain, Routledge. In: The Lower and Middle Palaeolithic periods in Britain, Routledge. 358 pp.

28. Chandler R (1916) The implements and cores of Crayford. Proc Prehist Soc 2:240-8

29. White M, Scott B, Ashton N (2006) The Early Middle Palaeolithic in Britain: archaeology, settlement history and human behaviour. J Quat Sci 21:525-41

30. Scott B, Bates M, Bates R, et al (2014) A new view from La Cotte de St Brelade, Jersey. Antiquity 88:13-29

31. Bates M, Pope M, Shaw A, et al (2013) Late Neanderthal occupation in North-West Europe: rediscovery, investigation and dating of a last glacial sediment sequence at the site of La Cotte de Saint Brelade, Jersey. J Quat Sci 28:647-52

32. Callow P, Cornford JM, McBurney CBM (1986) La Cotte de St. Brelade, 1961-1978: Excavations by C.B.M. McBurney, Geo Books, Norwich, $433 \mathrm{p}$

33. Wenban-Smith FF, Bates MR, Schwenninger JL (2010) Early Devensian (MIS 5d-5b) occupation at Dartford, southeast England. J Quat Sci 25:1193-9

34. White MJ, Pettitt PB (2011) The British Late Middle Palaeolithic: an interpretative synthesis of Neanderthal occupation at the northwestern edge of the Pleistocene world. J World Prehist 24:25-97

35. Boismier W, Schreve DC, White MJ, et al (2003) A Middle Palaeolithic site at Lynford Quarry, Mundford, Norfolk: Interim statement. Proc Prehist Soc 69:315-24

36. Schreve DC (2006) The taphonomy of a Middle Devensian (MIS 3) vertebrate assemblage from Lynford, Norfolk, UK, and its implications for Middle Palaeolithic subsistence strategies. J Quat Sci 21:543-56

37. Boismier WA, Gamble C, Coward F (2012) Neanderthals among mammoths: excavations at Lynford Quarry, Norfolk UK, English Heritage Monographs. In: English Heritage Monographs. 529 pp

38. Higham T, Douka K, Wood R, et al (2014) The timing and spatiotemporal patterning of Neanderthal disappearance. Nature 512:306-9

39. Higham T, Compton T, Stringer C, et al (2011) The earliest evidence for anatomically modern humans in northwestern Europe. Nature 479:521-4

40. Jacobi R, Higham T (2008) The "Red Lady" ages gracefully: New ultrafiltration AMS determinations from Paviland. J Hum Evol 55:898-907

41. Jacobi R, Higham T (2011) The British earlier Upper Palaeolithic: Settlement and chronology. In: Ashton NM, Lewis SG, Stringer CB (eds) The Ancient Human Occupation of Britain. Elsevier, Amsterdam, pp 181-222

42. Jacobi R, Higham T (2009) The early Lateglacial re-colonization of Britain: New radiocarbon evidence from Gough's Cave, southwest England. Quat Sci Rev 28:1895-913

43. Currant A, Jacobi R, Stringer CB (1989) Excavations at Gough's Cave, Somerset 1986 7. Antiquity 63:131-6 
44. Bello SM, Saladié P, Cáceres I, et al (2015) Upper Palaeolithic ritualistic cannibalism at Gough's Cave (Somerset, UK): The human remains from head to toe. J Hum Evol 82:170-89

45. Bello SM, Parfitt SA, Stringer CB (2011) Earliest directly-dated human skull-cups. PLoS One 6:e17026

46. Ripoll S, Muñz F, Bahn P, et al (2004) Palaeolithic Cave Engravings at Creswell Crags, England. Proc Prehist Soc 70:93-105

47. Woodward J (2014) The Ice Age: A very short introduction, OUP Oxford, $63 \mathrm{p}$

48. Shennan I, Horton B (2002) Holocene land- and sea-level changes in Great Britain. J Quat Sci 17:511-26

49. Bradley R (2014) The Prehistoric Settlement of Britain, Routledge, London, $172 \mathrm{p}$
50. Cramp LJE, Jones J, Sheridan A, et al (2014) Immediate replacement of fishing with dairying by the earliest farmers of the northeast Atlantic archipelagos. Proc R Soc B 281:e20132372

51. Penkman KE, Preece RC, Bridgland DR, et al (2011) A chronological framework for the British Quaternary based on Bithynia opercula. Nature 476:446-9

52. Debenham NC, Atkinson T, Grun R, et al (2012) Dating. In: Aldhouse-Green S, Peterson R, Walker EA (eds) Neanderthals in Wales: Pontnewydd and the Elwy Valley Caves. Oxbow Books, Oxford, pp 283-319

53. Pike AW, Gilmour M, Pettitt P, et al (2005) Verification of the age of the Palaeolithic cave art at Creswell Crags, UK. J Archaeol Sci $32: 1649-55$ 